\title{
LA MALA PALABRA
}

POR

LUISA VALENZUELA

Las niñas buenas no pueden decir esas cosas; las señoras elegantes, tampoco, ni las otras. No pueden decir ni esas cosas ni las otras, porque no hay posibilidad de acceso a lo positivo sin su opuesto, el negativo revelador y revelado. Tampoco las otras mujeres, las no tan señoras, pueden proferir aquellas palabras catalogadas de malas. Las grandes, las gordas: las palabrotas. Esas tan sabrosas al paladar, que llenan la boca. Palabrotas. Las que nos descargan de todo el horror contenido en un cerebro a punto ya de reventar. Hay palabras catárticas, momentos de decir que deberían ser inalienables y nos fueron alienados desde siempre.

Durante la infancia, las madres o los padres - por qué echarle la culpa siempre a las mujeres - nos lavaron a muchas de nosotras la boca con agua y jabón cuando decíamos alguna de esas llamadas palabrotas, las «malas» palabras. Cuando proferíamos nuestra verdad. Después vinieron tiempos mejores, pero esas interjecciones y esos apelativos nada cariñosos quedaron para siempre disueltos en la detergente burbuja del jabón que limpia hasta las manchas de familia. Limpiar, purificar la palabra, la mejor forma de sujeción posible. Ya lo sabían en la Edad Media, y así se siguió practicando en las zonas más oscuras de Bretaña, en Francia, hasta hace pocos años. A las brujas - y somos todas brujas hoy- se les lava la boca con sal roja para purificarlas. Canjeando un orificio por otro, como diría Margo Glantz, la boca era y sigue siendo el hueco más amenazador del cuerpo femenino: puede eventualmente decir lo que no debe ser dicho, revelar el oscuro deseo, desencadenar las diferencias amenazadoras que subvierten el cómodo esquema del discurso falocéntrico, el muy paternalista.

Y del dicho al hecho, de la palabra hablada a la palabra escrita: un solo paso. Que requiere toda la valentía de la que disponemos, porque 
parecería tan simple y no lo es, la escritura franqueará los abismos y, por tanto, hay que tener conciencia inicial del peligro, del abismo. Olvidarse de las bocas lavadas, dejar que las bocas sangren hasta acceder a ese territorio donde todo puede y debe ser dicho. Con la conciencia de que hay tanto por explorar, tanta barrera por romper, todavía.

Es una lenta e incansable tarea de apropiamiento, de transformación. De ese lenguaje hecho de «malas» palabras que nos fue vedado durante siglos y del otro lenguaje, el cotidiano, que estábamos obligadas a manejar con sumo cuidado, con respeto y fascinación porque de alguna manera no nos pertenecía. Ahora estamos rompiendo y reconstruyendo, es una ardua tarea. Ensuciando esas bocas lavadas, adueñándonos del castigo, sin permitirnos en absoluto la autolástima.

Entre nosotras el llanto está prohibido. Otras manifestaciones emotivas, otras emociones, no; pero sí el llanto, prohibido. Al celo, por ejemplo, podemos darle libre curso y alegrarnos. A los celos, en cambio, debemos mantenerlos bajo estricto control, podrían degenerar en llanto.

¿Por qué tanto miedo a las lágrimas? Porque las máscaras que usamos son de sal. Una sal roja, ardiente, que nos vuelve hieráticas y bellas, pero nos devora la piel.

Bajo las rojas máscaras tenemos el rostro en carne viva y las lágrín mas bien podrían disolver la sal y dejar al descubierto nuestras llagas. La peor penitencia.

Nos cubrimos con sal y la sal nos carcome y a la vez nos protege. Roja sal la más bella, la más voraz de todas. En tiempos idos nos restregaban la boca con la sal roja, queriendo lavarnos de impudicias. ¡Brujas!, gritaban ellos cuando algo perturbaba el tranquilizante orden por ellos instaurado. $Y$ nos fregaban la cara contra la roja sal de la ignominia y quedábamos anatemizadas para siempre. ¡Brujas!, os acusaban, acusaban, hasta que supimos apropiarnos de esa sal y nos hicimos las máscaras tan bellas. Iridiscentes, color carne, translúcidas de promesa.

Ahora ellos, si quieren besarnos - y todavía a veces quieren-deben besar la sal y quemarse a su vez los labios. Nosotras sabemos responder a los besos y no tenemos inconveniente de quemarnos con ellos desde el reverso de la máscara. Ellos/nosotras, nosotras/ellos. La sal ahora nos une, nos une la llaga y sólo el llanto podría separarnos.

Con máscara de sal nos acoplamos y a veces los sedientos vienen a lamernos. Es un placer perverso: ellos quedan con más sed que nunca y a nosotras nos duele y nos aterra la disolución de la máscara. Ellos lamen más y más, ellos gimen de desesperación, nosotras de dolor y de miedo. ¿Qué será de nosotras cuando afloren nuestros rostros ardidos? ¿Quién nos querrá sin máscara, quién en carne viva?

Ellos no. Ellos nos odiarán por eso, por habernos lamido, por haber- 
nos expuesto. Por habernos ellos lamido, por habernos ellos expuesto, ellos. $Y$ nosotras sin siquiera derramar una lágrima, sin permitirnos nuestro gesto más íntimo: la autodisolución de nuestra propia máscara gracias al prohibido llanto que abre surcos para empezar de nuevo.

Nuestra máscara es ahora el texto, el mismo que nosotras mismas, las mujeres, las dueñas de la textualidad y la textura, podemos — si queremos- disolver, y si no, no. Reconstruirlo, modificarlo, haciendo propias aquellas palabras que para otras eran malas - malas en nuestras bocas, claro está- y con aquello con que se nos estigmatizaba armarnos como siempre las corazas. Entre dos tapas. Espejarnos en el libro, en el texto, la otra cara del cuerpo femenino, aunque no tenga nada de aparentemente femenino, aunque despierte el dudoso cumplido que todas probablemente hemos escuchado alguna vez.

«Pero qué excelente novela (o cuento, o poema); parece escrito por un hombre!»

En un tiempo, quizá llegamos a sentirnos halagadas por tamaño despropósito. Ahora sabemos. Parece, pero no es. Porque lo que más hemos aprendido últimamente es a leer, a leer y a descifrar según nuestras propias claves.

Hace tanto, ya, que venimos lentamente escribiendo, cada vez con más furia, con más autorreconocimiento. Mujeres en la dura tarea de construir con un material signado por el otro. Construir no partiendo de la nada, que sería más fácil, sino transgrediendo las barreras de censura, rompiendo los cánones en busca de esa voz propia contra la cual nada pueden ni el jabón ni la sal gema, ni el miedo a la castración, ni el llanto. 
